Discussion Paper No. 08-013

\title{
The R\&D Investment-Uncertainty Relationship: Do Competition and Firm Size Matter?
}

Dirk Czarnitzki and Andrew A. Toole

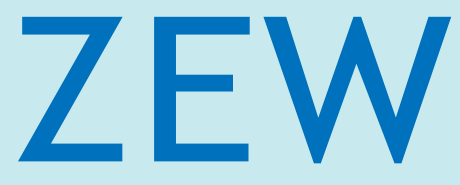

Zentrum für Europäische Wirtschaftsforschung $\mathrm{GmbH}$

Centre for European

Economic Research 
Discussion Paper No. 08-013

\title{
The R\&D Investment-Uncertainty Relationship: Do Competition and Firm Size Matter?
}

\author{
Dirk Czarnitzki and Andrew A. Toole
}

Download this ZEW Discussion Paper from our ftp server:

ftp://ftp.zew.de/pub/zew-docs/dp/dp08013.pdf

Die Discussion Papers dienen einer möglichst schnellen Verbreitung von neueren Forschungsarbeiten des ZEW. Die Beiträge liegen in alleiniger Verantwortung der Autoren und stellen nicht notwendigerweise die Meinung des ZEW dar.

Discussion Papers are intended to make results of ZEW research promptly available to other economists in order to encourage discussion and suggestions for revisions. The authors are solely responsible for the contents which do not necessarily represent the opinion of the ZEW. 


\section{Non-technical Summary}

Uncertainty is intrinsic to research and development (R\&D) and has a fundamental influence on the decision to invest in such activities. Real options theoretical models with irreversible investment are a natural starting point for understanding how uncertainty influences R\&D investment. When returns are uncertain and firms have the opportunity to delay investment, these models predict higher levels of uncertainty will be associated with lower levels of current R\&D investment. Other theoretical work, however, suggests this "option to delay" investment may not be valuable when firms face competitive pressure or when $R \& D$ investments create valuable growth opportunities. These mediating factors suggest the direction of the effect of uncertainty on R\&D investment is ambiguous.

This paper contributes to the literature by looking at how competition and firm size affect the R\&D investment-uncertainty relationship. We use an intuitively appealing measure of firm-level uncertainty along with panel data to show that firms invest less in current R\&D as uncertainty about market returns increases. The effect of firm-specific uncertainty on R\&D investment is smaller in concentrated markets - those where market power is higher and strategic rivalry is more intense. This is consistent with those theoretical models suggesting that growth options and the benefits of pre-emption offset the dampening effect of uncertainty. Further, the effect of uncertainty on R\&D investment is attenuated for large firms. This is consistent with models highlighting that uncertainty increases incentives for current investment when there are growth options. Large firms may have greater economies of scope relative to small firms. This permits both $R \& D$ knowledge and inputs to be transferred to alternative uses within the firm and can be interpreted as a form of capacity building highlighted in the growth options literature. 


\section{Zusammenfassung (Summary in German)}

Unsicherheit ist ein immanenter Faktor von Forschungs- und Entwicklung (FuE) und hat einen grundlegenden Einfluss auf Investitionsentscheidungen. Die Literatur zu „Real Options“ Modellen bildet eine Basis für empirische Analysen von Investitionsentscheidungen, insbesondere wenn es sich um größtenteils irreversible Ausgaben wie FuE-Aktivitäten handelt. Wenn Profite solcher Investitionsprojekte ungewiss sind und Unternehmen diese Investition verzögern können, zeigen ökonomische Theorien, dass bei höherer Unsicherheit weniger investiert wird. Jedoch gibt es auch Modelle, die beschreiben, dass die Option die Investition zu verzögern, nicht profitabel sein muss, wenn Unternehmen einem hohen Konkurrenzdruck ausgesetzt sind, oder wenn diese FuE-Aktivitäten hinreichende Wachstumsmöglichkeiten versprechen. Durch solche gegensätzlichen Anreize ist der Effekt von Unsicherheit auf das Investitionsverhalten nicht eindeutig.

In dieser Studie analysieren wir empirisch, wie Wettbewerb und Unternehmensgröße einen möglichen negativen Zusammenhang zwischen Investitionen und Unsicherheit beeinflussen. Mit Hilfe von Paneldaten können wir zeigen, dass Unternehmen bei höherer Unsicherheit über die erwarteten Profite tatsächlich weniger investieren. Jedoch ist der Effekt der firmenspezifischen Unsicherheit kleiner in konzentrierten Märkten sowie in Großunternehmen. Wir führen dies auf zwei Gründe zurück. In konzentrierten Märkten kann die strategische Interaktion zwischen Unternehmen intensiver sein als in anderen Märkten. Durch Innovationsaktivitäten kann ein Konkurrenzkampf in Produktmärkten vorweggenommen werden, sodass der negative Effekt von Unsicherheit reduziert wird. Ferner können Großunternehmen Erkenntnisse aus FuE-Aktivitäten besser in alternative Verwendungen transferieren als kleine Unternehmen („economies of scope“), was auch zur Reduktion der negativen Investitionsanreize unter Unsicherheit führt. 


\title{
The R\&D Investment-Uncertainty Relationship: Do Competition and Firm Size Matter? ${ }^{1}$
}

\author{
Dirk Czarnitzki ${ }^{\mathrm{a}, \mathrm{c}, \mathrm{d}}$ and Andrew A. Toole ${ }^{\mathrm{b}, \mathrm{d}}$ \\ a) K.U. Leuven, Dept. of Managerial Economics, Strategy and Innovation, Belgium \\ b) Rutgers University, NJ, Dept. of Ag, Food and Resource Economics, United States \\ c) Steunpunt $O \& O$ Indicatoren at K.U.Leuven \\ d) Centre for European Economics Research (ZEW), Mannheim, Germany
}

February 2008

\begin{abstract}
This paper investigates how competition and firm size affect the relationship between market uncertainty and R\&D investment. We use an intuitively appealing measure of firm-specific uncertainty along with panel data to show that firms invest less in current R\&D as uncertainty about market returns increases. The effect of firm-specific uncertainty on R\&D investment is smaller in concentrated markets those where market power is higher and strategic rivalry is more intense. Further, the effect of uncertainty on R\&D investment is attenuated for large firms which may be the result greater economies of scope.
\end{abstract}

Keywords: $\quad$ Real Options Theory, Uncertainty, R\&D, Competition, Firm Size

JEL Classification: O31, L11, G31

Address:

Dirk Czarnitzki

K.U.Leuven

Dept. of Managerial Economics,

Strategy and Innovation

Naamsestraat 69

3000 Leuven

Belgium

Phone: $\quad+3216326906$

E-Mail: $\quad$ dirk.czarnitzki@econ.kuleuven.be
Andrew A Toole

Rutgers University

Dept. of Ag, Food and Resource

Economics

55 Dudley Road

New Brunswick, NJ 08901

USA

+1 (732) 932-9155 ext. 215

toole@aesop.rutgers.edu

\footnotetext{
${ }^{1}$ We are grateful to the MIP team at ZEW Mannheim for providing the survey data.
} 


\section{Introduction}

Uncertainty is intrinsic to research and development (R\&D) and has a fundamental influence on the decision to invest in such activities. Real options theoretical models with irreversible investment are a natural starting point for understanding how uncertainty influences $R \& D$ investment. When returns are uncertain and firms have the opportunity to delay investment, these models predict higher levels of uncertainty will be associated with lower levels of current R\&D investment (Dixit and Pindyck 1994; Caballero and Pindyck 1996; Novy-Marx 2007; and others). ${ }^{2}$ Other theoretical work, however, suggests this "option to delay" investment may not be valuable when firms face competitive pressure or when R\&D investments create valuable growth opportunities (Caballero 1991; Grenadier 2002; Weeds 2002; Kulatilaka and Perotti 1998; and others). These mediating factors suggest the direction of the effect of uncertainty on $R \& D$ investment is ambiguous.

There is a surprising paucity of evidence in the empirical literature on how uncertainty influences R\&D investment and we found no published studies looking at the mediating roles played by competition and growth opportunities. ${ }^{3}$ In some recent work,

\footnotetext{
2 The theoretical literature we cite in this paper uses general models of investment that are not typically specialized to a particular type of capital investment such as R\&D.

${ }^{3}$ There is a growing empirical literature on the relationship between fixed capital investment and uncertainty at the firm-level. Recent contributions include Baum et al. (2007), Bloom et al. (2007), Bulan (2005). Butzen and Fuss (2002) and Carruth et al. (2000) review the prior literature. Using industry data, Ghosal and Loungani (1996) find that physical capital investment falls in response to price uncertainty in competitive industries, but has no significant response in industries with high seller concentration. In another analysis, Ghosal and Loungani (2000) find that investment is more responsive to uncertainty in industries dominated by small firms.
} 
Czarnitzki and Toole (2007) find that higher uncertainty, measured as the volatility in a firm's share of new product sales, reduces R\&D investment. Analyzing a sample of OECD countries, Goel and Ram (2001) find that greater uncertainty, measured as the standard deviation in a country's inflation rate, reduces the share of R\&D in GDP but has no significant effect on the share of non-R\&D investment in GDP. Minton and Schrand (1999) find that cash flow volatility is associated with lower R\&D investment using a sample of public firms in the US.

This paper contributes to the literature by looking at how competition and firm size affect the R\&D investment-uncertainty relationship. We use an intuitively appealing measure of firm-level uncertainty along with panel data to show that firms invest less in current R\&D as uncertainty about market returns increases. The effect of firm-specific uncertainty on R\&D investment is smaller in concentrated markets - those where market power is higher and strategic rivalry is more intense. This is consistent with those theoretical models suggesting that growth options and the benefits of pre-emption offset the dampening effect of uncertainty, but not with the theoretical results of Caballero (1991). Further, the effect of uncertainty on R\&D investment is attenuated for large firms. This is consistent with models highlighting that uncertainty increases incentives for current investment when there are growth options. Large firms may have greater economies of scope relative to small firms. ${ }^{4}$ This permits both R\&D knowledge and inputs to be transferred to alternative uses within the

Using firm-level survey data, Guiso and Parigi (1999) find that firms with low market power (more competitive industries) are less responsive to uncertainty than firms with more market power.

\footnotetext{
${ }^{4}$ For large pharmaceutical firms, Henderson and Cockburn (1996) find economies of scope to be a significant advantage for research productivity.
} 
firm and can be interpreted as a form of capacity building highlighted in the growth options literature.

\section{Data and Empirical Model}

\subsection{Data}

We construct an unbalanced panel database consisting of 881 "innovative" firms from Germany’s manufacturing sector observed between 1995 and 2001. ${ }^{5}$ An innovative firm is defined as a company that introduced at least one new product in the pre-sample period, that is, before the firm enters the panel database. To determine the firm-year observations in our database, we require the firm to be observed at least three times before the corresponding year $t$. We use these pre-sample years to generate some of the explanatory variables including our proxy for the firm's perceived uncertainty in the market for innovations. Our final database has 2,974 firm-year observations which are structured as follows: $21 \%$ of firms are observed twice, $23 \%$ three times, $21 \%$ four times, and the remaining $36 \%$ are observed between 5 and 7 times.

The log-level of current $\mathrm{R} \& \mathrm{D}$ investment for firm $i$ at time $t,\left(\ln R \& D_{i t}\right)$, is our dependent variable. ${ }^{6}$ Consistent with what one would expect from real options behavior, one-

\footnotetext{
${ }^{5}$ Our data come from the Mannheim Innovation Panel which is an annual survey conducted by the Center for European Economic Research (ZEW). The panel is unbalanced because firms do not respond to the survey in every year. The first survey year was 1992.

${ }^{6}$ The distribution of R\&D investment is skewed above zero and this motivates our use of the logarithmic specification. Since we cannot take the log of the censored observations at $R \& D_{i}=0$, we set those observations to the minimum observed positive value of $R \& D$ in the sample and interpret this observed minimum as the
} 
third of the innovative firms with positive $R \& D$ in the past have at least one observation with zero R\&D investment in subsequent years. Since our sample has a number of smaller private firms (the median number of employees per firm is 110 ), R\&D investment is intermittent. ${ }^{7}$ In regression models, we account for the censored distribution of R\&D using a Tobit model.

We assume firms use their past market experience as innovators to form their expectations about future market uncertainty. Market uncertainty is measured by the coefficient of variation of past sales. We distinguish two components of past sales since our data allow us to explicitly account for sales of new products introduced in the most recent three years and sales of established products. Hence, we calculate $U N C \_N E W$, the coefficient of variation of new product sales, and $U N C \_O L D$, the coefficient of variation of older, more established product sales. To eliminate firm size effects in sales volume, we rescale the sales revenues by the number of firm employees. The number of observations available for calculating the coefficients of variation depend on year of entry into the panel and the number of observations varies from three to nine years depending on data availability $(\mathrm{s}=1, \ldots, \mathrm{S}$, with $\mathrm{S}$ ranging between 3 and 9$):^{8}$

censoring point in the regression models. R\&D is measured in millions of Deutsche Marks DM $(1.95583 \mathrm{DM}=$ 1 EURO).

${ }^{7}$ This is consistent with real option behavior because the trigger values for investing and abandoning projects are higher and lower, respectively, than those predicted from standard net present value analysis. See NovyMarx (2007) for a discussion of the implications from intermittent and lumpy investment behavior in a real options theoretical model.

${ }^{8}$ For the regression models presented below, we performed robustness checks to test the sensitivity of our results to the length of the pre-sample period used. This did not materially affect our results. If desired, these results can be obtained from the authors. 
(1) $U N C_{i t}=\frac{\sqrt{\frac{1}{S} \sum_{s=1}^{S}\left[\frac{R_{i, t-s}}{L_{i, t-s}}-\left(\frac{1}{S} \sum_{s=1}^{S} \frac{R_{i, t-s}}{L_{i, t-s}}\right)\right]^{2}}}{\frac{1}{S} \sum_{s=1}^{S} \frac{R_{i, t-s}}{L_{i, t-s}}}$,

where $R$ refers to sales with new products or sales with old products, respectively, and $L$ denotes employment.

Since we are interested in how competition and firm size affect the R\&D investmentuncertainty relationship, we create interaction variables between uncertainty and our measures of industry competition and firm size. The competitiveness of an industry is measured using the seller concentration given by the Herfindahl index based on shares of total market sales at the 3-digit NACE level, $\ln (H H I) .{ }^{9}$ We define industries in the upper quintile of the distribution of the Herfindahl index as highly concentrated indicating a high degree of market power and strategic rivalry. Firm size is measured using the number of employees in the firm. We define a firm as large when it has more than 500 employees. In our sample, $18 \%$ of the firms are large. We checked the cut points for concentration and firm size for robustness and this is discussed in the results section below.

Papers by Caballero and Pindyck (1996) and Leahy and Whited (1996) highlight that greater industry-level and systematic (economy-wide) uncertainties are associated with lower current investment. To control for these sources of uncertainty, we calculate an industrylevel measure of uncertainty and use a full set of industry and time dummy variables in the models. We calculate the coefficient of variation of total industry sales over time at the 3-

\footnotetext{
${ }^{9} \mathrm{NACE}$ is the European standard industry classification.
} 
digit NACE level obtained from German industry statistics $\left(U N C_{-} I N D_{i t-1}\right){ }^{10}$ We also construct a proxy for firm-specific risk preferences using the firm's recent product innovation strategy. That is, firms with an aggressive product innovation strategy should be the least risk-averse firms, while those following a conservative innovation strategy should be the most risk-averse. The firm's relative innovativeness (PASTINNO) is calculated using its average share of new product sales relative to its industry in the pre-sample period (the same period over which we calculate our uncertainty measure).

We use the firm's patent stock, PSTOCK ${ }_{i t-1}$, to control for existing R\&D capabilities. It is calculated with data from the German Patent and Trademark Office. Those data cover German patents (including EPO priority applications with German coverage) since 1978. We cumulate each firm's patents from 1978 forward using a 15\% annual obsolescence rate of knowledge (see e.g. Griliches and Mairesse, 1984, or Hall, 1990, for details). This control variable enters our models in lagged form to avoid simultaneity.

Our specifications control for access to internal and external financial capital. For the availability of internal capital, we use a measure of the firm's average price-cost margin, $(P A S T P C M)$, in the pre-sample period: ${ }^{11}$

\footnotetext{
${ }^{10}$ As we do not have information about employment at this detailed industry level, we do not normalize industry sales by the number of employees, but rather, the number of firms active in that industry in a given year.

11 See Collins and Preston (1969), or Ravenscraft (1983). Scholars who have used such measures to test for financial constraints typically add back R\&D to PCM, as R\&D is an expense and reduces profits in the period. If the firm would have decided not to invested in R\&D, PCM would have been accordingly higher and is therefore corrected by current R\&D in most empirical studies (see e.g. Harhoff, 1998).
} 
(2) $\quad$ PASTPCM $_{i, t-1}=\frac{1}{S} \sum_{s=1}^{S} P C M_{i, t-s}$

with $P C M=($ Sales - staff cost - material cost $+\mathrm{R} \& \mathrm{D}) /$ Sales,

As a proxy for access to external credit, we use the firm's credit rating from Creditreform, the largest German credit rating agency. We use the rating in period $t-1$ in order to avoid endogeneity problems. ${ }^{12}$ The rating is an index ranging from 100 to 600 , where 600 hundred is the worst and basically corresponds to bankruptcy.

Finally, we include a location dummy, $\mathrm{EAST}_{\mathrm{i}}$, indicating that the firm is based in Eastern Germany. These firms may show different investment behavior, on average, due to the German re-unification in 1990. Table 1 presents descriptive statistics of all variables used. Note that all time-variant variables enter the right-hand side of the regressions as lagged values, so that they can be treated as predetermined.

\section{>> Insert Table 1 about here $<<<$}

\subsection{Empirical Model}

We use two different estimators for our panel data, a pooled cross-sectional and a random effects panel estimator. The model can be written as

$$
\begin{aligned}
& y_{i t}=\max \left(0, x_{i t} \beta+c_{i}+u_{i t}\right), \quad i=1,2, \ldots, N, \quad t=1,2, \ldots, T \\
& u_{i t} \mid x_{i}, c_{i} \sim N\left(0, \sigma_{u}^{2}\right)
\end{aligned}
$$

\footnotetext{
${ }^{12}$ For some firms, there was no rating available for the preceding year. In such cases we use ratings from one or two years earlier.
} 
where $y_{i t}$ is the dependent variable, $x_{i t}$ denotes the set of regressors, $\beta$ the parameters to be estimated, and $c_{i}$ the unobserved firm-specific effect, and $u_{i t}$ is the error term. First, we assume that $c_{i}=0$, and thus the model can be estimated as a pooled cross-sectional model where we adjust the standard errors for firm clusters to account for the panel structure of the data. The pooled model has the advantage that it does not maintain the strict exogeneity assumption. While $u_{i t}$ has to be independent of $x_{i t}$, the relationship between $u_{i t}$ and $x_{i s}, t \neq s$, is not specified (see Wooldridge, 2002: 538). For instance, the model allows for feedback of $\mathrm{R} \& \mathrm{D}$ in period $t$ to the regressors in future periods. In the second version of the model, we apply a random-effects Tobit panel estimator assuming $c_{i} \neq 0$. This requires the strict exogeneity assumption so the error term needs to be uncorrelated with the covariates across all time periods. In addition, the random-effects Tobit requires the assumption that $c_{i}$ is uncorrelated with $x_{i t}$. Due to these stronger assumptions, we do not necessarily consider the random effect estimator as superior to the pooled cross-sectional estimator. Rather we think of it as a robustness check allowing for unobserved firm-specific effects at the cost of more restrictive assumptions otherwise. Note that we keep the time-invariant regressors (EAST and industry dummies) in the random-effects panel model in order to reduce the error variance of the firm-specific effect.

\section{Results}

Table 2 presents our regression results. We consider three versions of the empirical specification: model $\mathrm{A}$ is the baseline specification and excludes the interaction variables between market uncertainty, competition, and firm size. Model B examines how the R\&D investment-uncertainty relationship is mediated by competition. Model $\mathrm{C}$ looks at how the R\&D investment-uncertainty relationship differs between large and small firms. In models B and $\mathrm{C}$ we estimate separate slope coefficients of uncertainty for each group of interest. In 
model $\mathrm{B}$, the groups are concentrated versus less concentrated industries. In model $\mathrm{C}$, the groups are large versus small firms.

Model A finds that uncertainty in the market for new products significantly reduces firm-level R\&D investment. This is consistent with prior studies even though those studies use different uncertainty proxies and databases (Minton and Schrand 1999; Czarnitzki and Toole 2007). Uncertainty in the market for established products has no significant relationship with current $R \& D$ investment in any of the regression models in Table 2. This stands to reason since R\&D investment is directed predominantly toward innovation rather than cannibalization of established product sales. Given the insignificance of uncertainty related to established product, the rest of the paper uses the term "uncertainty" to refer to uncertainty in market for new products.

Among the control variables, industry-level uncertainty is not significant in either the pooled or random-effects regressions. This is similar to prior work on physical capital investment by Leahy and Whited (1996) who looked at the CAPM relationship and Bulan (2005) who considers irreversible investment (neither of these studies examine R\&D). Our proxy for firm risk preferences (PASTINNO) has the correct sign, but is only marginally significant in the random effects models A and B. The Herfindahl index is not significant in either model. For the financing variables, internal funds are positive and significant in the pooled model, but because there is not a lot of variation over time, it is insignificant in the random effects panel model. Access to external capital is not significant in either model. Patent stock, employment, and the Eastern Germany dummy variable are significant in both pooled and random effects models. Because the results for the control variables are very similar across models, we will not discuss these variables further.

Model B looks at how competition influences the firm-level R\&D investmentuncertainty relationship. When the distribution of Herfindahl index is partitioned at the 
eightieth percentile, both models show that firms in upper quintile respond less to uncertainty. The Chi-squared test reported at the bottom of Table 2 shows a statistically significant difference across the two groups. We believe that these highly concentrated industries involve more intense strategic interaction and rivalry. This finding is consistent with the predictions from some theoretical models that illustrate how strategic interactions erode the option value of waiting (Grenadier 2002; Weeds 2002; Kulatilaka and Perotti 1998). ${ }^{13}$ It contradicts the findings of Guiso and Parigi (1999), but they examine physical capital investment. If other cutoff points in the distribution of concentration are chosen, the firm-level responses to uncertainty become more similar. We re-estimated the model using the $70 \%, 60 \%$ and $50 \%$ quantiles of $\mathrm{HHI}$ as cutoff points. The difference in the estimated slopes coefficients decreases as the cutoff point is moved downwards in the distribution. While the estimated coefficient for more concentrated markets is still slightly larger than the one for less concentrated markets when the sample is split at the median of HHI, there is no statistically significant difference among them anymore. Both estimated coefficients approach the value of the non-interacted slope in model A.

Model $\mathrm{C}$ examines how firm size influences the firm-level $\mathrm{R} \& \mathrm{D}$ investmentuncertainty relationship. Large firms respond less to market uncertainty than small firms. The Chi-squared test shows a statistically significant difference across the two groups. These results are not driven by financial constraints since we control for internal and external access

\footnotetext{
${ }^{13}$ Note that strategic interaction as we have measured it does not completely erode the option value of waiting as Grenadier's model predicts. Since the option value of waiting is still relatively large for low concentration markets (i.e. those closer to perfectly competitive markets), our evidence appears to be more consistent with the model presented by Novy-Marx (2007). However, our empirical analysis is not a formal test of the differences between these models.
} 
to financial capital. If large firms maintain a more diverse portfolio of research projects that allow $R \& D$ personnel and equipment to be used in more than one application at no additional cost, then these "economies of scope" can offset the influence of uncertainty by providing growth options.

\section{>>> Insert Table 2 about here $\quad<<<$}

We also calculated marginal effects for both models, that is, $\mathrm{dE}(\mathrm{Y} \mid \mathrm{X}) / \mathrm{dx}$. The estimated marginal effects at the mean of uncertainty amount to -1.61 and -2.73 for large versus small firms (significantly different at $1 \%$ level), and -1.93 and -2.71 for highly concentrated industries vs. others (different at 5\% level). As these numbers are somewhat difficult to interpret economically, we illustrate the impact of uncertainty on R\&D over the range of the uncertainty distribution in Figure 1. It can be seen that the slope of the curve (the marginal effect) is more negative for smaller firms and for firms in highly concentrated industries compared to their respective control groups over a large range of the distribution.

\section{>>> Insert Figure 1 about here $\quad<<$}

\section{Conclusions}

This paper has empirically examined how competition and firm size affect the R\&D investment-uncertainty relationship. Our evidence suggests that strategic rivalry tends to erode the option value for waiting to invest in $\mathrm{R} \& \mathrm{D}$, but not completely. We also find that 
large firms react less to market uncertainty which is consistent with the idea that large firms enjoy greater diversification and economies of scope in R\&D activities.

There are a number of issues that remain for future research. First, our measure of uncertainty is intuitively appealing but is based on prior firm experience. To be completely consistent with theory, one needs an explicitly forward-looking measure. Second, while our firm-level panel data make a significant step forward in the analysis of firm-specific uncertainty, the time series dimension of our data is not rich enough to model the dynamics of the R\&D investment-uncertainty relationship. Third, new empirical measures that capture economies of scope at the firm-level would allow researchers to analyze the mechanisms driving down real options values for large firms in greater detail.

\section{References}

Baum, C.F., M. Mustafa, and O. Talavera. 2007. Uncertainty Determinants of Firm Investment, Economics Letters, Forthcoming.

Bloom, N., S. Bond, and J. Van Reenen. 2007. Uncertainty and Investment Dynamics. Review of Economic Studies, 74: 391-415.

Bulan, L.T. 2005. Real Options, Irreversible Investment and Firm Uncertainty: New Evidence from U.S. Firms. Review of Financial Economics 14(3/4): 255-279.

Butzen, R., and C. Fuss. 2002. Firms' Investment and Finance Decisions. Northampton, MA: Edward Elgar Publishing.

Caballero, R.J. 1991. On the Sign of the Investment-Uncertainty Relationship, American Economic Review, 81(1): 279-288.

Caballero, R. J., and R.S. Pindyck. 1996. Uncertainty, Investment, and Industry Evolution, International Economic Review, 37(3): 641-662. 
Carruth, A., A. Dickerson and A. Henley. 2000. What do we know about investment under uncertainty? Journal of Economic Surveys 14(2): 119-153.

Collins, N.R. and L.E. Preston. 1969. Price-cost margins and industry structure. Review of Economics and Statistics 51(3): 271-286.

Czarnitzki, D., and A.A. Toole. 2007. Business R\&D and the Interplay of R\&D Subsidies and Product Market Uncertainty, Review of Industrial Organization, forthcoming.

Dixit, A.K., and R.S. Pindyck. 1994. Investment Under Uncertainty. Princeton: Princeton University Press.

Goel, R.K. and R. Ram. 2001. Irreversibility of R\&D investment and the adverse effect of uncertainty: Evidence from the OECD countries. Economic Letters 71(2): 287-291.

Ghosal, V., and P. Loungani. (1996). Product Market Competition and the Impact of Price Uncertainty on Investment: Some Evidence from US Manufacturing Industries, Journal of Industrial Economics, 44(2), 217-228.

Ghosal, V., and P. Loungani. (2000). The Differential Impact of Uncertainty on Investment in Small and Large Businesses, Review of Economics and Statistics, 82(2), 338-349.

Grenadier, S.R. 2002. Option Exercise Games: An Application to the Equilibrium Investment Strategies of Firms, The Review of Financial Studies, 15(3): 691-721.

Griliches, Z., and J. Mairesse. 1984. Productivity and R\&D at the Firm Level, in: Z. Griliches (ed.), R\&D, Patents and Productivity. Chicago, 339-374.

Gusio, L., and G. Parigi (1999). Investment and Demand Uncertainty, Quarterly Journal of Economics, 114(1), 188-227.

Hall, B.H. 1990. The manufacturing sector master file: 1959-1987. NBER Working Paper No. 3366. Cambridge, MA. 
Harhoff, D. 1998. Are There Financing Constraints for R\&D and Investment in German Manufacturing Firms? Annales d'Economie et de Statistique 49/50: 421-456.

Henderson, R., and I. Cockburn. 1996. Scale, Scope, and Spillovers: The Determinants of Research Productivity in Drug Discovery, The RAND Journal of Economics, 27(1): 32-59.

Kulatilaka, N., Perotti, E.C. 1998. Strategic Growth Options. Management Science 44(8): 1021-1031.

Leahy, J.V., and T.M. Whited. 1996. The Effect of Uncertainty on Investment: Some Stylized Facts. Journal of Money, Credit and Banking, 28(1): 64-83.

Minton, B.A, Schrand, S. 1999. The impact of cash flow volatility on discretionary investment and the costs of debt and equity financing. Journal of Financial Economics 54: 423-460.

Novy-Marx, R. 2007. An Equilibrium Model of Investment Under Uncertainty. Review of Financial Studies 20(5): 1461-1502.

Ravenscraft, D.J. 1983. Structure-profit relationships at the line of business and industry level. Review of Economics and Statistics 65: 22-31.

Weeds, H. 2002. Strategic Delay in a Real Options Model of R\&D Competition. Review of Economic Studies 69: 729-747.

Wooldridge, J.M. 2002. Econometric Analysis of Cross Section and Panel Data. Cambridge, MA: The MIT Press. 
Table 1: Descriptive Statistics (2974 firm-year observations)

\begin{tabular}{lrrrr}
\hline Variable & Mean & Std. Dev. & Min & Max \\
\hline R\&D $_{\text {it }}$ & 9.514 & 96.347 & 0 & 3000 \\
UNC_NEW $_{\mathrm{i}, \mathrm{t}-1}$ & 0.942 & 0.695 & 0.009 & 3 \\
UNC_OLDD $_{\mathrm{i},-1}$ & 0.510 & 0.371 & 0.011 & 2.449 \\
UNC_IND $_{\mathrm{i}, \mathrm{t}-1}$ & 0.118 & 0.105 & 0.009 & 1.067 \\
PASTINNO $_{\mathrm{i}, \mathrm{t}-1}$ & 1.412 & 1.041 & 0.006 & 6.934 \\
PASTPCM $_{\mathrm{i}, \mathrm{t}-1}$ & 0.275 & 0.139 & -0.373 & 0.827 \\
EMP $_{\mathrm{i}, \mathrm{t}-1}$ & 509.322 & 2493.741 & 1 & 45000 \\
PSTOCK $_{\mathrm{i}, \mathrm{t}-1} / \mathrm{EMP}_{\mathrm{i}, \mathrm{t}-1}$ & 0.018 & 0.044 & 0 & 0.370 \\
HHI $_{\mathrm{i}, \mathrm{t}-1}$ & 48.379 & 71.485 & 3.213 & 1000 \\
RATING $_{\mathrm{i},-\mathrm{t}-1}$ & 215.507 & 66.301 & 100 & 600 \\
EAST $_{\mathrm{i}}$ & 0.375 & 0.484 & 0 & 1 \\
Large [D(EMP $\left.\left._{\mathrm{i}, \mathrm{t}-1-1}>500\right)\right]$ & 0.145 & 0.352 & 0 & 1 \\
\hline
\end{tabular}

Note: 10 industry dummies and 6 time dummies not shown. 
Table 2: Tobit regressions on $\ln \left(R \& D_{i t}\right), 1995-2001,2974$ firm-year observations

\begin{tabular}{|c|c|c|c|c|c|c|}
\hline \multirow[b]{2}{*}{ Variable } & \multicolumn{2}{|c|}{ Model A } & \multicolumn{2}{|c|}{ Model B } & \multicolumn{2}{|c|}{ Model C } \\
\hline & Pooled Tobit ${ }^{\text {a) }}$ & RE Panel Tobit & Pooled Tobit $^{\text {a) }}$ & RE Panel Tobit & Pooled Tobit $^{\mathrm{a})}$ & RE Panel Tobit \\
\hline $\mathrm{UNC}_{-} \mathrm{NEW}_{\mathrm{i}, \mathrm{t}-1}$ & $\begin{array}{l}-4.369 * * * \\
(0.301)\end{array}$ & $\begin{array}{l}-3.386 * * * \\
(0.274)\end{array}$ & & & & \\
\hline $\mathrm{UNC}_{-} \mathrm{NEW}_{\mathrm{i}, \mathrm{t}-1} * \mathrm{D}\left(\mathrm{HHI}_{\mathrm{i}, \mathrm{t}-1}>\mathrm{Q}_{80}\right)$ & & & $\begin{array}{l}-3.254^{* * *} \\
(0.518)\end{array}$ & $\begin{array}{l}-2.524 * * * \\
(0.427)\end{array}$ & & \\
\hline $\mathrm{UNC}_{-} \mathrm{NEW}_{\mathrm{i}, \mathrm{t-1}} * \mathrm{D}\left(\mathrm{HHI} \mathrm{i}_{\mathrm{it-1}-1} \leq \mathrm{Q}_{80}\right)$ & & & $\begin{array}{l}-4.570 * * * \\
(0.299)\end{array}$ & $\begin{array}{l}-3.538^{* * *} \\
(0.282)\end{array}$ & & \\
\hline $\mathrm{UNC}_{-} \mathrm{NEW}_{\mathrm{i}, \mathrm{t}-1} *$ LARGE FIRM & & & & & $\begin{array}{l}-2.717 * * * \\
(0.610)\end{array}$ & $\begin{array}{l}-1.662 * * * \\
(0.493)\end{array}$ \\
\hline UNC_NEW $_{\mathrm{i}, \mathrm{t-1}} *$ SMALL FIRM & & & & & $\begin{array}{l}-4.610 * * * \\
(0.303)\end{array}$ & $\begin{array}{l}-3.638 * * * \\
(0.280)\end{array}$ \\
\hline UNC_OLD ${ }_{i, t-1}$ & $\begin{array}{r}-0.235 \\
(0.344)\end{array}$ & $\begin{array}{r}0.034 \\
(0.362)\end{array}$ & $\begin{array}{r}-0.253 \\
(0.345)\end{array}$ & $\begin{array}{r}0.129 \\
(0.294)\end{array}$ & $\begin{array}{r}-0.277 \\
(0.345)\end{array}$ & $\begin{array}{r}-0.005 \\
(0.362)\end{array}$ \\
\hline UNC_IND ${ }_{i, t-1}$ & $\begin{array}{r}0.537 \\
(1.567)\end{array}$ & $\begin{array}{r}0.708 \\
(1.181)\end{array}$ & $\begin{array}{r}0.440 \\
(1.561)\end{array}$ & $\begin{array}{r}0.602 \\
(1.180)\end{array}$ & $\begin{array}{r}-0.454 \\
(1.621)\end{array}$ & $\begin{array}{r}0.282 \\
(1.190)\end{array}$ \\
\hline PASTINNO $_{\mathrm{i},-1-1}$ & $\begin{array}{r}0.143 \\
(0.158)\end{array}$ & $\begin{array}{l}0.282 * \\
(0.170)\end{array}$ & $\begin{array}{r}0.157 \\
(0.157)\end{array}$ & $\begin{array}{l}0.288^{*} \\
(0.169)\end{array}$ & $\begin{array}{r}0.136 \\
(0.159)\end{array}$ & $\begin{array}{r}0.275 \\
(0.169)\end{array}$ \\
\hline PASTPCM $_{\mathrm{i}, \mathrm{t}-1}$ & $\begin{array}{l}2.035 * * \\
(0.974)\end{array}$ & $\begin{array}{r}1.380 \\
(0.976)\end{array}$ & $\begin{array}{l}2.131 * * \\
(0.975)\end{array}$ & $\begin{array}{r}1.420 \\
(0.973)\end{array}$ & $\begin{array}{l}1.842 * \\
(0.969)\end{array}$ & $\begin{array}{r}1.308 \\
(0.963)\end{array}$ \\
\hline $\ln \left(\mathrm{EMP}_{\mathrm{i}, \mathrm{t}-1}\right)$ & $\begin{array}{l}1.458 * * * \\
(0.098)\end{array}$ & $\begin{array}{l}1.546^{* * * *} \\
(0.101)\end{array}$ & $\begin{array}{l}1.471^{* * * *} \\
(0.098)\end{array}$ & $\begin{array}{l}1.549 * * * \\
(0.101)\end{array}$ & $\begin{array}{l}1.255^{* * * *} \\
(0.107)\end{array}$ & $\begin{array}{l}1.341^{* * * *} \\
(0.112)\end{array}$ \\
\hline PSTOCK $_{i, t-1} /$ EMP $_{i, t-1}$ & $\begin{array}{l}9.799 * * * \\
(2.006)\end{array}$ & $\begin{array}{l}9.727 * * * \\
(2.665)\end{array}$ & $\begin{array}{l}9.827 * * * \\
(2.013)\end{array}$ & $\begin{array}{l}9.740 * * * \\
(2.660)\end{array}$ & $\begin{array}{l}9.545 * * * \\
(1.999)\end{array}$ & $\begin{array}{l}9.376^{* * * *} \\
(2.685)\end{array}$ \\
\hline $\ln \left(\mathrm{HHI}_{\mathrm{i}, \mathrm{t}-1)}\right.$ & $\begin{array}{r}-0.122 \\
(0.144)\end{array}$ & $\begin{array}{r}0.022 \\
(0.137)\end{array}$ & $\begin{array}{l}-0.398^{* *} \\
(0.166)\end{array}$ & $\begin{array}{r}-0.197 \\
(0.161)\end{array}$ & $\begin{array}{r}-0.137 \\
(0.142)\end{array}$ & $\begin{array}{r}0.003 \\
(0.137)\end{array}$ \\
\hline $\ln \left(\mathrm{RATING}_{\mathrm{i}, \mathrm{t}-1}\right)$ & $\begin{array}{r}0.261 \\
(0.599)\end{array}$ & $\begin{array}{r}-0.159 \\
(0.522)\end{array}$ & $\begin{array}{r}0.208 \\
(0.599)\end{array}$ & $\begin{array}{r}-0.191 \\
(0.524)\end{array}$ & $\begin{array}{r}0.399 \\
(0.592)\end{array}$ & $\begin{array}{r}-0.051 \\
(0.521)\end{array}$ \\
\hline $\mathrm{EAST}_{\mathrm{i}}$ & $\begin{array}{l}0.879 * * * \\
(0.324)\end{array}$ & $\begin{array}{l}0.973 * * * \\
(0.317)\end{array}$ & $\begin{array}{l}0.919 * * * \\
(0.321)\end{array}$ & $\begin{array}{l}0.988 * * * \\
(0.316)\end{array}$ & $\begin{array}{l}0.905 * * * \\
(0.323)\end{array}$ & $\begin{array}{l}0.968 * * * \\
(0.314)\end{array}$ \\
\hline Intercept & $\begin{array}{l}-13.626 * * * \\
(3.719)\end{array}$ & $\begin{array}{l}-13.826 * * * \\
(3.159)\end{array}$ & $\begin{array}{l}-12.557 * * * \\
(3.714)\end{array}$ & $\begin{array}{l}-12.973 * * * \\
(3.178)\end{array}$ & $\begin{array}{l}-13.188 * * * \\
(3.667)\end{array}$ & $\begin{array}{l}-13.207 * * * \\
(3.146)\end{array}$ \\
\hline
\end{tabular}




\section{Table 2 continued}

\begin{tabular}{|c|c|c|c|c|c|c|}
\hline Joint significance of industry dummies $\left(\chi^{2}(10)\right)$ & $72.68 * * *$ & $98.79 * * *$ & $73.48 * * *$ & $98.04 * * *$ & $78.52 * * *$ & $104.20 * * *$ \\
\hline Joint significance of time dummies $\left(\chi^{2}(6)\right)$ & $124.57 * * *$ & $141.39 * * *$ & $125.11 * * *$ & $142.98 * * *$ & $123.19 * * *$ & $139.89 * * *$ \\
\hline $\begin{array}{l}\text { Joint test on difference of slope coefficients of } \\
\text { UNC_NEW variables }\left(\chi^{2}(1)\right)\end{array}$ & & & $7.11 * * *$ & $7.00 * * *$ & $10.50 * * *$ & $17.79 * * *$ \\
\hline Log-Likelihood & -6161.79 & -5958.67 & -6153.38 & -5955.22 & -6146.09 & -5950.19 \\
\hline McFadden- $R^{2}$ & 0.145 & 0.173 & 0.146 & 0.160 & 0.147 & 0.163 \\
\hline
\end{tabular}

Note: Standard errors in parentheses. $* * *(* * *)$ indicate a significance level of $1 \%(5 \%, 10 \%)$

a) Standard errors are clustered at the firm-level ( 881 clusters). 
Figure 1: Estimated effects of new product market uncertainty on $R \& D$ investment

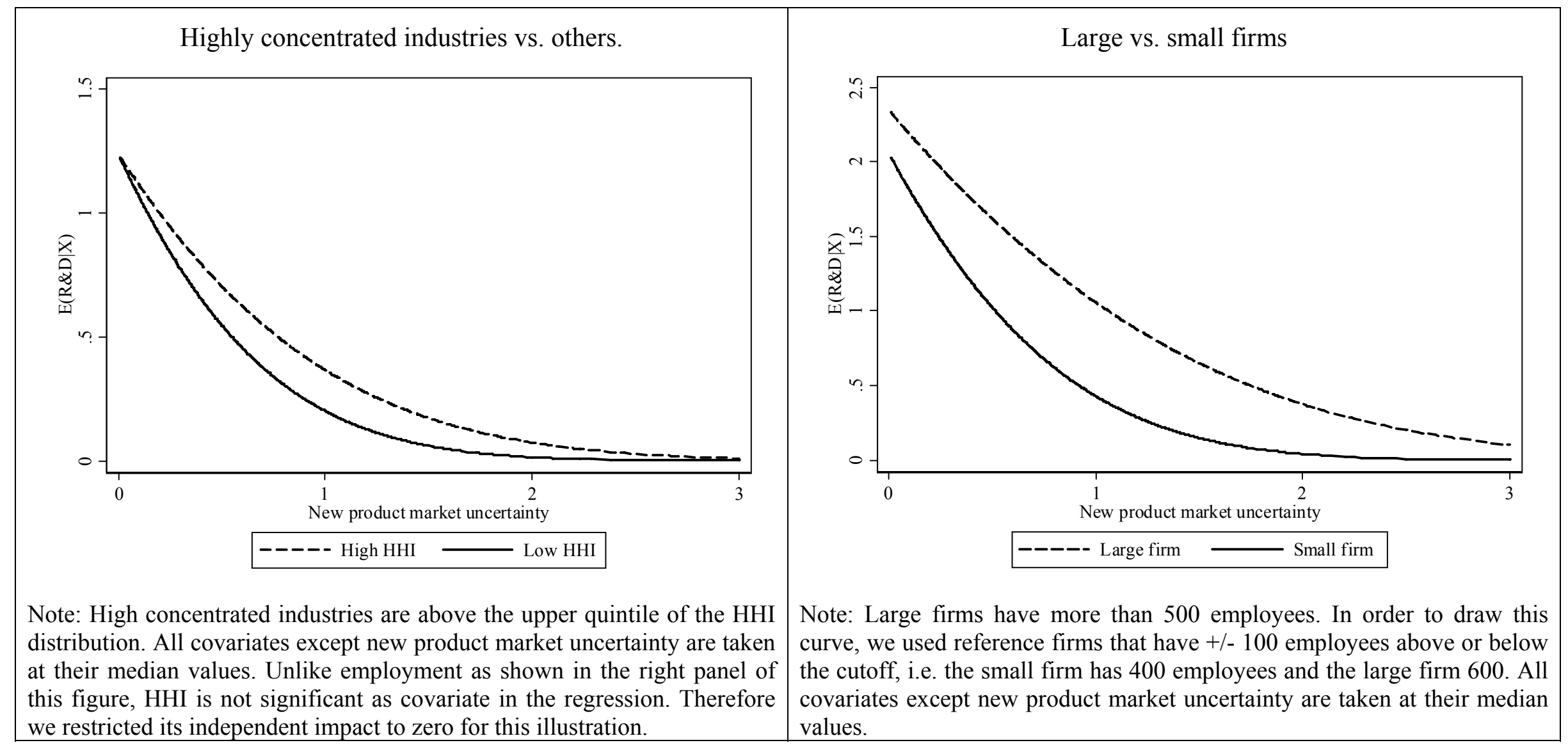

